\title{
Review
}

\section{Fetal Hemoglobin Inducers from the Natural World: A Novel Approach for Identification of Drugs for the Treatment of $\beta$-Thalassemia and Sickle-Cell Anemia}

\author{
Nicoletta Bianchi ${ }^{1,2}$, Cristina Zuccato ${ }^{1}$, llaria Lampronti ${ }^{1,2}$, Monica Borgatti ${ }^{1}$ and \\ Roberto Gambari ${ }^{1,2}$
}

${ }^{1}$ ER-GenTech, Department of Biochemistry and Molecular Biology, Section of Molecular Biology, University of Ferrara and ${ }^{2}$ GenTech-for-Thal, Laboratory for the Development of Pharmacological and Pharmacogenomic Therapy of Thalassaemia, Biotechnology Centre, Ferrara, Italy

\begin{abstract}
The objective of this review is to present examples of lead compounds identified from biological material (fungi, plant extracts and agro-industry material) and of possible interest in the field of a pharmacological approach to the therapy of $\beta$-thalassemia using molecules able to stimulate production of fetal hemoglobin $(\mathrm{HbF})$ in adults. Concerning the employment of $\mathrm{HbF}$ inducers as potential drugs for pharmacological treatment of $\beta$-thalassemia, the following conclusions can be reached: (i) this therapeutic approach is reasonable, on the basis of the clinical parameters exhibited by hereditary persistence of fetal hemoglobin patients, (ii) clinical trials (even if still limited) employing $\mathrm{HbF}$ inducers were effective in ameliorating the symptoms of $\beta$-thalassemia patients, (iii) good correlation of in vivo and in vitro results of $\mathrm{HbF}$ synthesis and $\gamma$-globin mRNA accumulation indicates that in vitro testing might be predictive of in vivo responses and (iv) combined use of different inducers might be useful to maximize $\mathrm{HbF}$, both in vitro and in vivo. In this review, we present three examples of $\mathrm{HbF}$ inducers from the natural world: (i) angelicin and linear psoralens, contained in plant extracts from Angelica arcangelica and Aegle marmelos, (ii) resveratrol, a polyphenol found in grapes and several plant extracts and (iii) rapamycin, isolated from Streptomyces hygroscopicus.
\end{abstract}

Keywords: fetal hemoglobin - $\beta$-thalassemia-rapamycin-medicinal plants - resveratrol-red wine-psoralens

\section{$\beta$-Thalassemias, Sickle Cell Anemia (SCA) and Hereditary Persistance of Fetal Hemoglobin (HPFH)}

The $\beta$-thalassemias are characterized by a very heterogeneous group of inherited mutations causing abnormal expression of globin genes, leading to total absence or quantitative reduction of synthesis of $\beta$-globin chains (1-3).

For reprints and all correspondence: Prof. Roberto Gambari, GenTech-for-Thal, Laboratory for the Development of Pharmacological and Pharmacogenomic Therapy of Thalassaemia, Biotechnology Centre, Ferrara, Italy. Tel: + 390532 974443; Fax: + 390532 974500;

E-mail: gam@unife.it
This disease is frequent in the Mediterranean area, Middle East, Africa and Asia. The reduction of $\beta$-globin chains is associated with a corresponding excess of the complementary $\alpha$-globin chain in erythroid cells that causes premature hemolysis of red blood cells and destruction of erythroid precursors in the bone marrow and extramedullary sites (ineffective erythropoiesis) (4-7). More than 200 different mutations have been identified in $\beta$-thalassemia patients $(1-3,8,9)$, including deletions of the $\beta$ or $\delta \beta$ gene region, stop codons leading to premature termination of a non-functional $\beta$-globin chain, mutations suppressing correct maturation of the $\beta$-globin RNA precursor. 
Table 1. Inducers of differentiation and $\mathrm{HbF}$ in human erythroid cells*

\begin{tabular}{|c|c|}
\hline Inducers & Mechanism of action \\
\hline $\mathrm{HU}$ & Inhibition of DNA synthesis \\
\hline 5-Azacytidine and citarabine & Hypomethylation of DNA \\
\hline $\begin{array}{l}\text { Butyrates, tricostatin, } \\
\text { apicidin and scriptaid }\end{array}$ & Inhibition of HDAC activity \\
\hline $\begin{array}{l}\text { Mithramycin, cisplatin and analogues, } \\
\text { tallimustine and analogues, angelicin }\end{array}$ & DNA-binding activity \\
\hline Rapamycin and everolimus & $\begin{array}{l}\text { FRAP-mTOR signal } \\
\text { transduction targeting }\end{array}$ \\
\hline Triple-helix oligonucleotides & $\begin{array}{l}\text { Activation of } \gamma \text {-globin } \\
\text { gene transcription }\end{array}$ \\
\hline Peptide nucleic acids (PNAs) & $\begin{array}{l}\text { Sequence-selective } \\
\text { promoter activation }\end{array}$ \\
\hline
\end{tabular}

*Modified from Gambari and Fibach (55).

SCA is a common recessively inherited disorder of hemoglobin caused by a point mutation affecting the coding sequence of the $\beta$-globin gene, causing a substitution of glutamic acid by valine at the sixth position of $\beta$-globins of hemoglobin $\mathrm{S}(\mathrm{HbS})(10)$. This amino acid substitution leads to a drastic reduction in the solubility of the deoxy form of HbS. Under hypoxic conditions, deoxy$\mathrm{HbS}$ molecules polymerize inside the cells, forming rigid, sickled cells. SCA is highly frequent in sub-Saharan Africa, the Middle East and Mediterranean areas, the Indian subcontinent, the Caribbean and South America. The homozygous state of SCA is associated with complications and a reduced life expectancy $(10,11)$.

Several observations lead to the conclusion that production of fetal hemoglobin $(\mathrm{HbF})$ can functionally compensate for the absence of $\beta$-globin chain production (12-15), including the very interesting finding that a group of genetic mutations, known as hereditary persistence of fetal hemoglobin (HPFH), are associated with high levels of $\mathrm{HbF}$ in adults (16-19) resulting in a mild phenotype. Most of the HPFH patients homozygous for $\beta$-thalassemia do not need blood transfusion. Therefore, there has been considerable interest in recent years in finding ways of increasing production of $\mathrm{HbF}$ and reactivate the $\gamma$-globin genes (20-29).

In Table 1, a list of $\mathrm{HbF}$ inducers is reported. Unfortunately, several of these drugs have low efficacy and specificity, and some of them are potentially carcinogenic. Therefore, there is an urgent need to (i) develop experimental model systems for a large screening of $\mathrm{HbF}$ inducers and (ii) identify new types of agents that can induce $\mathrm{HbF}$ production with greater efficiency and lower toxicity (20).

\section{Clinical Trials}

Clinical trials aimed at increasing $\mathrm{HbF}$ synthesis in $\beta$-thalassemia and SCA patients have included administration of cell-cycle-specific agents, hematopoietic growth
Table 2. Clinical trials employing $\mathrm{HU}$ as in vivo inducer of fetal hemoglobin

\begin{tabular}{|c|c|c|c|}
\hline $\begin{array}{l}\text { Number of } \\
\text { patients } \\
\text { treated }^{\mathrm{a}}\end{array}$ & $\begin{array}{l}\text { Genotype/ } \\
\text { phenotype }^{b}\end{array}$ & $\begin{array}{l}\text { Number } \\
\text { of patients } \\
\text { responding } \\
\text { to the } \\
\text { treatment }^{\mathrm{c}}\end{array}$ & References \\
\hline 2 & $\begin{array}{c}\beta \text {-Thalassemia } \\
\text { intermedia }\end{array}$ & $2(100 \%)$ & Bradai et al., (31) \\
\hline 5 & $\begin{array}{l}\beta \text {-Thalassemia } \\
\text { major }\end{array}$ & $5(100 \%)$ & Bradai et al. (31) \\
\hline 36 & $\begin{array}{l}\beta \text {-Thalassemia } \\
\text { major }\end{array}$ & $25(69 \%)$ & Alebouyeh et al. (32) \\
\hline 133 & $\begin{array}{l}\beta \text {-Thalassemia } \\
\text { major }\end{array}$ & $81(61 \%)$ & Yavarian et al. (30) \\
\hline 37 & $\begin{array}{c}\beta \text {-Thalassemia } \\
\text { intermedia }\end{array}$ & $26(70 \%)$ & Dixit et al. (33) \\
\hline 166 & $\begin{array}{c}\beta \text {-Thalassemia } \\
\text { intermedia }\end{array}$ & $83(50 \%)$ & Karimi et al. (34) \\
\hline 42 & $\mathrm{HbE} / \beta^{\circ}$-Thalassemia & $50 \%$ & Singer et al. (35) \\
\hline
\end{tabular}

${ }^{\mathrm{a}}$ Dosages were $5-20 \mathrm{mg} \mathrm{kg}^{-1} \mathrm{day}^{-1}$; ' ${ }^{\mathrm{b}}$ Only patients needing transfusions are included; ${ }^{\mathrm{c}}$ Transfusion-free patients.

factors and short-chain fatty acids, all of which stimulate $\gamma$-globin synthesis by different mechanisms. Compounds such as 5-azacytidine, hydroxyurea (HU) and butyrate analogues have been used most frequently (30-39) (Table 2). As a representative example, Yavarian et al. (30) reported the treatment with $\mathrm{HU}$ in 133 patients diagnosed with transfusion-dependent $\beta$-thalassemia. These patients were classified into three categories of response: a good response $(61 \%)$ in patients who shifted from monthly blood transfusion dependency to a stable transfusion-free condition; a moderate response $(23 \%)$ in patients who remained transfusion dependent but at longer intervals (6 months or more), and non-response in patients who, after 1 year of treatment, remained at the same level of transfusion dependency. As far as demethylating agents tested in Phase I/II studies, decitabine, used at DNA hypomethylating, but non-cytotoxic doses, was well tolerated and effective in increasing $\mathrm{HbF}$ and total $\mathrm{Hb}$ levels in patients affected by hemoglobin disorders $(40,41)$. Therapy with butyrates has been also reported (42). When all these clinical data are considered together, it appears that $\mathrm{HbF}$ inducers are clinically beneficial for patients affected by $\beta$-thalassemia and SCA.

\section{Experimental Model Systems to Identify Novel Inducers of Fetal Hemoglobin}

\section{Reporter Genes under the Transcriptional Control of the $\gamma$-Globin Promoter}

Several groups described the use of reporter genes [such as luciferase and green fluorescence protein (GFP)] under the transcriptional control of the 

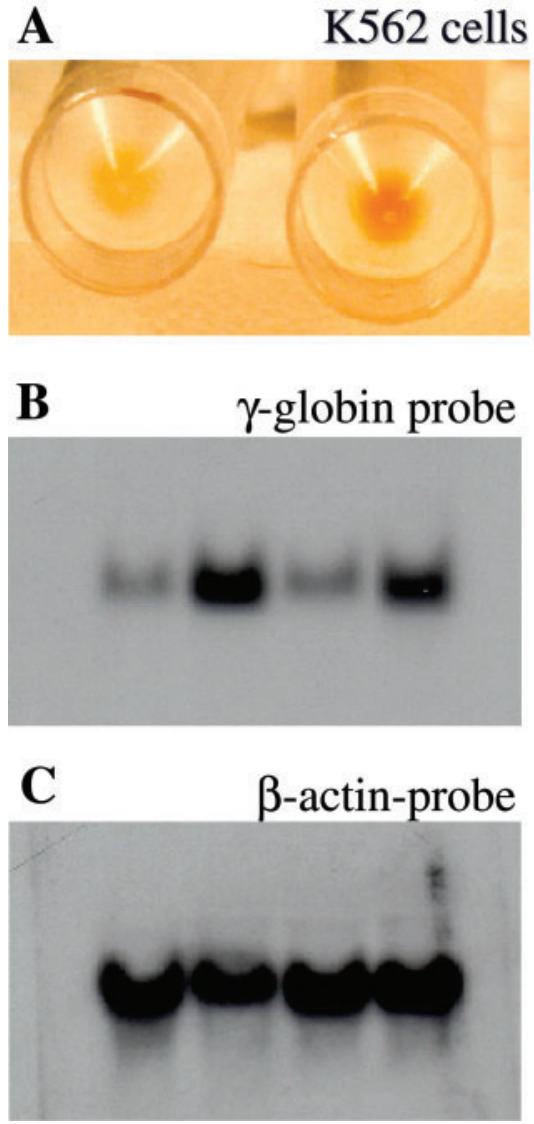
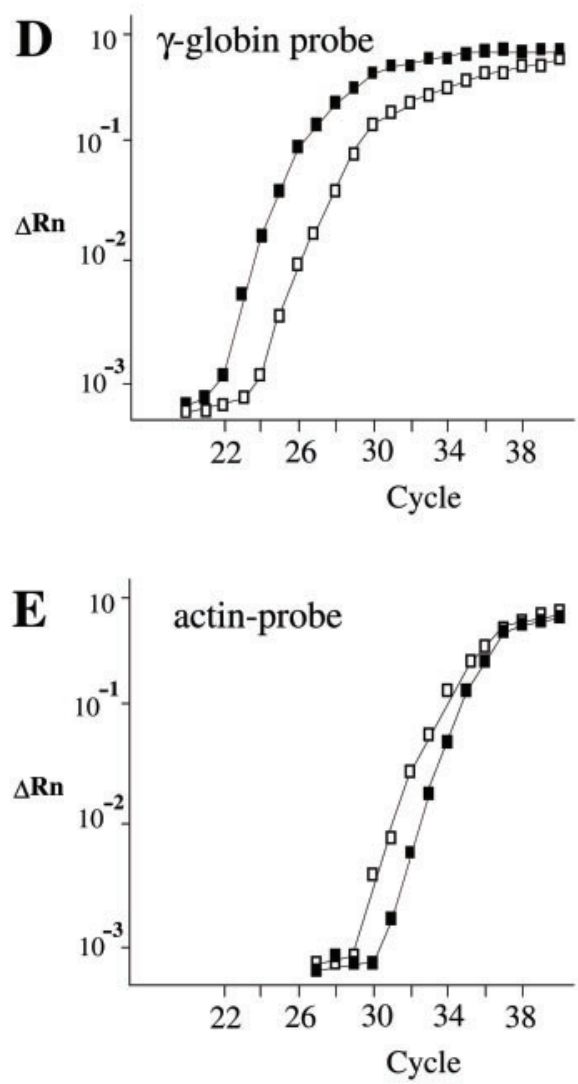
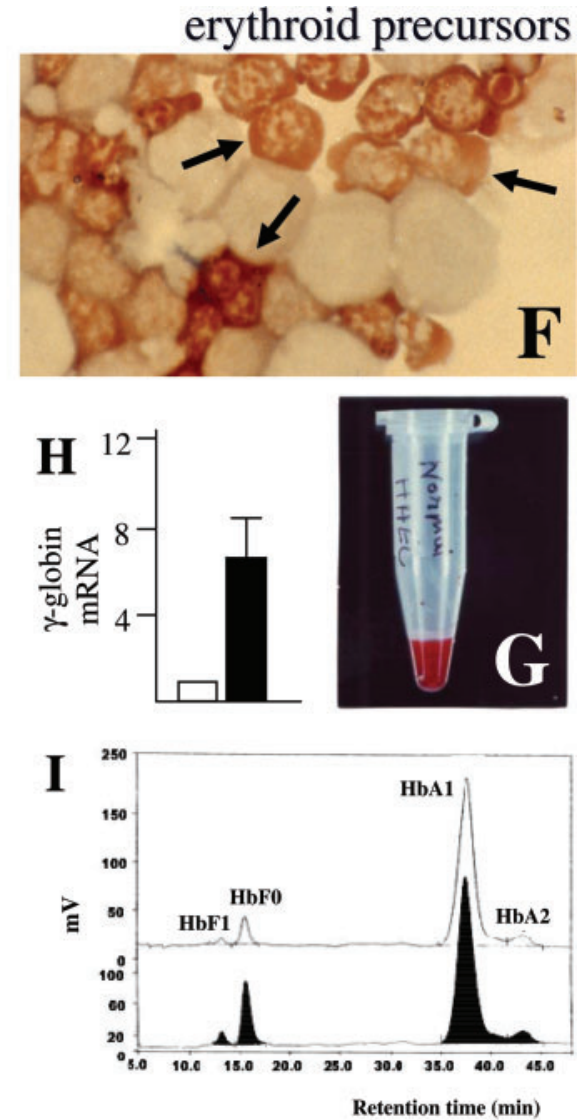

Figure 1. The K562 and human erythroid precursors cell systems for screening of inducers of HbF. (A) Pellets of uninduced (left) and erythroid induced (right) K562 cells. Only pellets from induced cells are red, indicating hemoglobin production. (B,C) Northern blotting analysis of uninduced and erythroid induced cells. Hybridization was carried on with a $\gamma$-globin (B) or a $\beta$-actin (C) probes. The increase of signal in erythroid induced cells (B, lines 2 and 4 from the left) indicates an increase of production of $\gamma$-globin mRNA. Minor changes are observed studying actin mRNA (C). (D,E) Quantitative RT-PCR analysis documenting the increase of $\gamma$-globin mRNA in K562 cells following induction (black squares) (D); minor changes were found in analysis of actin mRNA content (E). (F) Erythroid cells in culture. Benzidine staining of cells from day 8 Phase II cultures. Cells were smeared on a glass slide using a cytocentrifuge, and stained with benzidine. Mature erythroid Hb-containing cells, which are benzidine positive $\left(\mathrm{B}^{+}\right)$are arrowed. (G) A red pellet of erythroid precursor cells. (H) Fold increase of $\gamma$-globin mRNA content in erythroid precursor cells treated with mithramycin in comparison to control untreated cells (white box). (I) HPLC chromatogram of hemoglobins produced by cultured erythroid cells. Control (upper chromatogram) and erythroid-induced (lower chromatogram) cells were harvested from day 12 cultures, washed and lysed. The hemoglobins in the lysate were separated on cation-exchange HPLC. The peaks are labeled with the corresponding hemoglobin type. Increase in the proportion of $\mathrm{HbF}$ is detectable in lysates from erythroid induced cells. Modified from Gambari and Fibach (55).

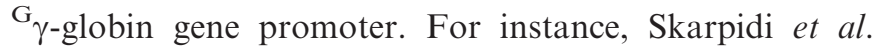
(43) developed a rapid and efficient method for detecting $\mathrm{HbF}$ inducers, based on a recombinant DNA construct in which the coding sequences of two different luciferase reporter genes, firefly and renilla, are substituted for those

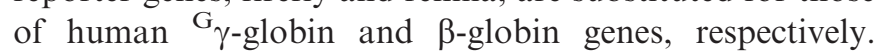
Cellular genomic reporter assays for screening and evaluation of $\mathrm{HbF}$ inducers were also developed by introducing reporter genes within an intact $\beta$-globin gene locus. This approach has described and validated by Vadolas et al. (44), who developed a stable cellular genomic reporter assays based on the GFP gene under the

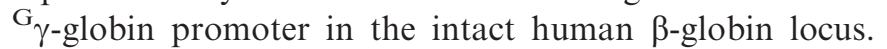
The results obtained firmly demonstrate that both these approaches are suitable for the high-throughput screening of molecules able to increase $\gamma$-globin promoter directed transcription (45).

\section{Human Erythroid-like K562 Cells}

The human erythroid-like K562 cell line, isolated and characterized by Lozzio and Lozzio (46) from a patient with chronic myelogenous leukemia in blast crisis, has been extensively employed as a very useful in vitro model to study the molecular mechanism(s) regulating the expression of embryonic and fetal human globin genes (47), as well as to determine the therapeutic potential of new differentiation-inducing compounds (47-51). K562 cells grow in culture as single, undifferentiated, cells in suspension, with low production of hemoglobins (see Fig. 1A, left). 
When stimulated by various agents, they respond within few days with a significant increase in the production of hemoglobins and $\gamma$-globin mRNA (Fig. 1A-E) (51).

\section{Erythroid Progenitors from Peripheral Blood}

Large cultures of relatively pure and synchronized erythroid cell population can be obtained from peripheral blood and compounds can be added on different days when the culture consists of cells at specific stages of maturation. In the procedure developed by Fibach et al. (52), the culture is divided into two phases: an EPOindependent phase, in which peripheral blood cells are first cultured in the presence of a combination of growth factors, but in the absence of EPO. In the second phase, the culture, supplemented with EPO, generates orthochromatic normoblasts that differentiate, decrease in size and accumulate $\mathrm{Hb}$, generating aggregates assuming a reddish color (Fig. 1F, arrowed cells). This system recapitulates many aspects of in vivo erythropoiesis including globin RNA metabolism, cell cycle kinetics, expression of cell surface antigens, iron and ferritin metabolism and transcription factors (53-55). Therefore, several research groups have used this system to study the effects of hundreds of compounds, including butyroids (52), hemin (53) and EPO (54). The globin gene expression can be monitored analyzing the fold increase of globin mRNA in respect to control untreated cells (Fig. 1H). Hb content of the developing erythroid cells (Fig. 1G) can be measured by a variety of techniques, the most used of which is cation-exchange HPLC for hemoglobins (Fig. 1I).

\section{Correlation Between In Vitro Effects of HbF Inducers and In Vivo Treatment}

As far as predictivity of in vitro analyses is concerned, several data suggests a correlation between the in vitro results on erythroid precursor cells isolated from $\beta$-thalassemia and SCA patients and the response of the treated patients to therapy. The correlation of in vivo and in vitro results of $\mathrm{HbF}$ synthesis and $\gamma$-globin mRNA suggest that in vitro testing may predict the in vivo response (55). This will prevent both expensive and potentially risky treatment from patients who do not respond to treatment and suggest an alternative treatment (e.g. by other agents).

\section{Inducers of $\mathrm{HbF}$ Production}

The studies published on potential $\mathrm{HbF}$ inducers indicate that they can be grouped in several classes, with different mechanisms of action (Table 1) (55). Several inducers inhibit histone deacethylase (HDAC) activity (26). While most inducers display inhibitory effects on cell growth, a limited number of them stimulate increase of $\mathrm{HbF}$ without effecting cell proliferation (55). Erythroid precursor cells from $\beta$-thalassemia patients differ in their
Table 3. Inducers of $\mathrm{HbF}$ from natural sources

\begin{tabular}{llll}
\hline Inducer & Source & Biological effects & References \\
\hline Bergaptene & A. marmelos & $\begin{array}{l}\text { Erythroid } \\
\text { differentiation } \\
\text { of K562 cells }\end{array}$ & Lampronti et al. (65) \\
Angelicin & A. arcangelica & HbF production & Lampronti et al. (78) \\
Rapamycin & S. hygroscopicus & HbF production & Mischiati et al. (114) \\
Resveratrol & $\begin{array}{c}\text { Red wine, grape } \\
\text { skin and } \\
\text { darakchasava }\end{array}$ & HbF production (116) & Rodrigue et al. (101) \\
Mithramycin & $\begin{array}{c}\text { Streptomyces } \\
\text { species }\end{array}$ & HbF production & Bianchi et al. (51) \\
& & Fibach et al. (77) \\
\hline
\end{tabular}

response to the same inducer. Furthermore, a combined use of $\mathrm{HbF}$ inducers displaying a different mechanism of action might improve the results. Finally, the use of oligonucleotide (ODN)-based approach might help in designing specific treatments for different types of $\beta$-thalassemia (55).

\section{HbF Inducers from the Natural World}

Several reviews and papers have been published on the possible use of extracts from medicinal plants for biomedical purposes (56-65) including therapeutic strategies for the treatment of a number of diseases such as dyslipidemia (66) and aterosclerosis (67), hepatitis (68), inflammatory diseases $(69,70)$, osteoporosis $(62)$, bacterial and virus infections (71-73).

In the case of hemoglobinopathies, only few examples are available. For instance, Niprisan (Nix-0699), a ethanol/ water extract developed in Nigeria from indigenous plants, has a strong antisickling effect, demonstrated by a significant prolongation of the delay time prior to deoxy$\mathrm{HbS}$ polymerization when compared with that of untreated HbS samples. The solubility of deoxy-HbS significantly increased upon treatment with Nix-0699. Niprisan was found to improve the survival rates of transgenic sickle-cell mice under acute severe hypoxic conditions. Finally, a Phase II study suggests that this phytomedicine is effective in reducing episodes of SCA crisis associated with severe pain over a 6-month period, in 82 participants $(74,75)$.

On the contrary, in respect to the employment of products from the natural world for $\mathrm{HbF}$ production, few data are available (Table 3). We present in this review some recently reported examples.

\section{Linear and Angular Furocoumarins: Potent Inducers of Erythroid Differentiation and $\mathrm{HbF}$ Production}

A possible employment of plant extracts on the identification of novel $\mathrm{HbF}$ inducers has been obtained studying the antiproliferative activity of several extracts from medicinal plants on different tumor cell lines, 

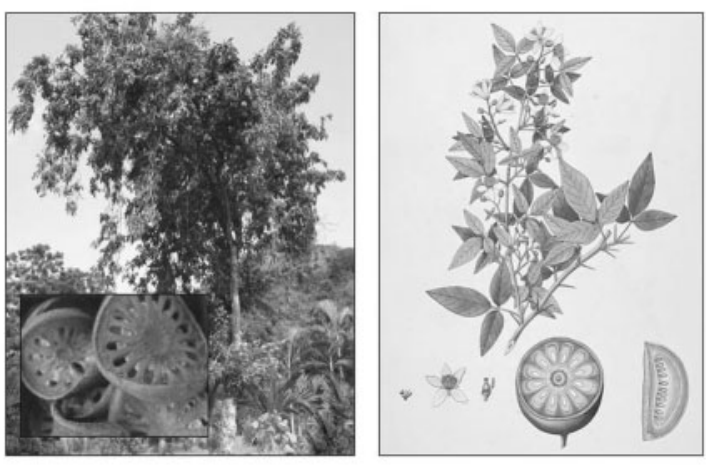

Aegle marmelos

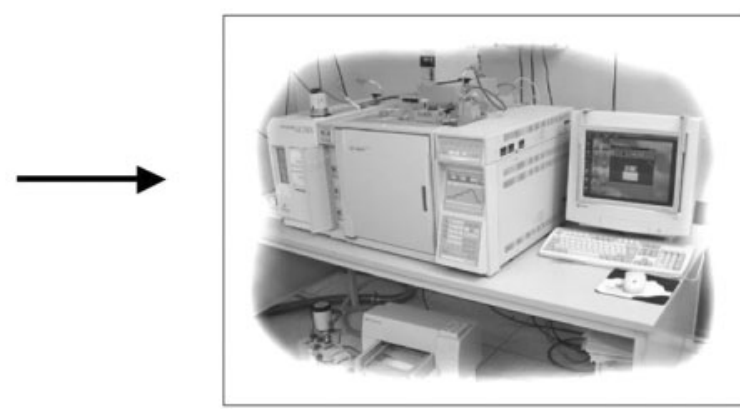

GC/MS
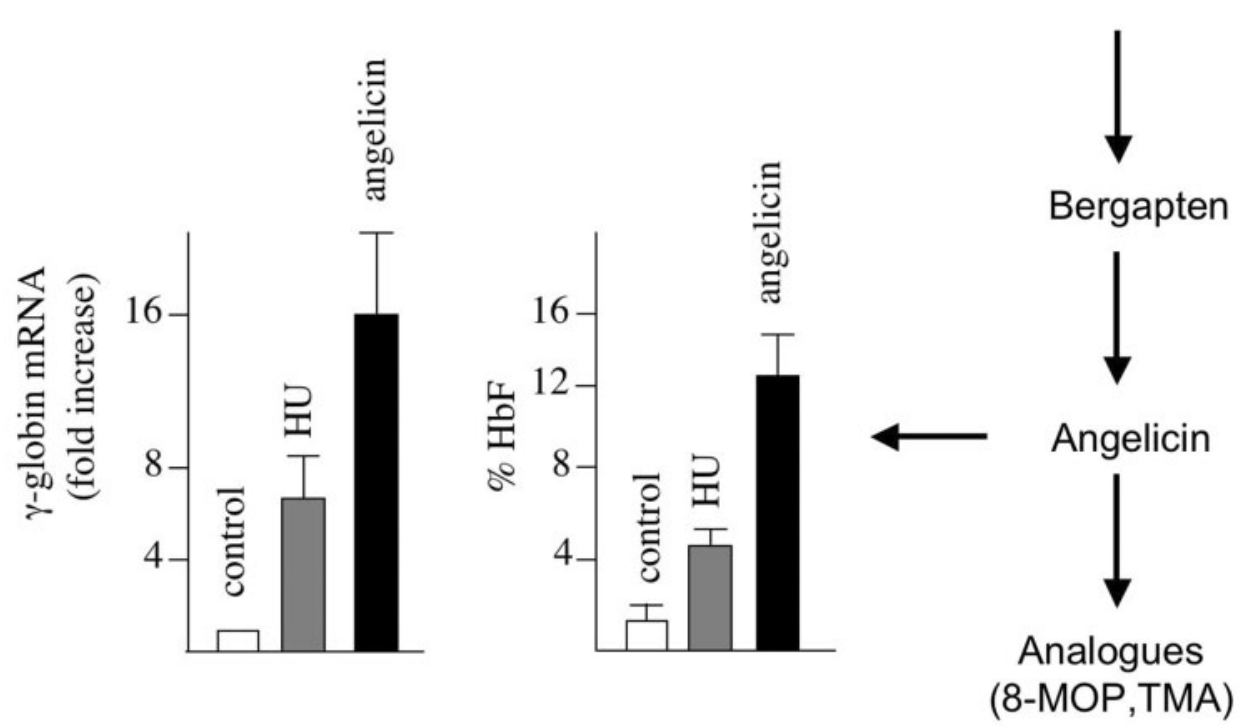<smiles>O=c1ccc2ccc3occc3c2o1</smiles>

Figure 2. Identification of linear and angular furocoumarins as inducers of HbF. Scheme depicting the experimental approach to identify bergapten (5-MOP) in extracts from A. marmelos (78). The structures of bergapten and the angular analogue angelicin are shown in the right part of the panel. The fold increase of $\gamma$-globin mRNA and the percentage of HbF in erythroid precursor cells from human healthy donors are shown in the lower-left part of the panel. The content of $\gamma$-globin mRNA has been quantified by RT-PCR, the percentage of HbF by HPLC. These data are modified from Lampronti et al. (78).

including the K562 cell line (64). Interestingly, antiproliferative activity of extracts from Aegle marmelos on K562 cells was found to be associated with activation of erythroid induction (65). As published in several papers, $\mathrm{HbF}$ inducers are usually potent inducers of K562 cells $(55,76,77)$. Accordingly, GC/MS analysis of A. marmelos allowed us to identify several molecules, including 5-methoxypsoralen (5-MOP, Fig. 2), which we demonstrated to be responsible for erythroid induction of K562 cells (78). 5-MOP belongs to a well-known class of molecules (psoralen derivatives) that have been extensively studied in the past (79-90) and demonstrated to retain interesting biological effects on eukaryotic cells, allowing biomedical applications and the development of clinical trials (90-100). The biological importance of furocoumarins mainly focuses on their more relevant applications in photochemotherapy as pointed out in several reviews (97-99). In particular, psoralens have been proposed and used in psoralens-UVA treatment (PUVA) for psoriasis, vitiligo and mycosis fungoides (T-cell lymphoma) (98). It is generally accepted that these molecules cause cell damage by covalent binding to DNA following UVA irradiation; in fact, they exhibit a planar tricyclic structure with two photoreactive sites (3,4-pyrone and 4',5'-furan double bonds). The initial intercalation and interaction with double-stranded DNA are not characterized by covalent bonds, but, upon absorption of a photon of UVA, a pyrimidine residue (preferentially a thymine) of the DNA, covalently binds to the first photoreactive site with a 5,6-double bond. The resulting monoadduct can form a diadduct by absorbing a second photon, if a new pyrimidine on the opposite strand of DNA is available for an interstrand cross-link. On the contrary, angular psoralens (such as angelicin), are monofunctional isopsoralen isomers and cannot create interstrand cross-links because of their angular geometric structure (81-83). 

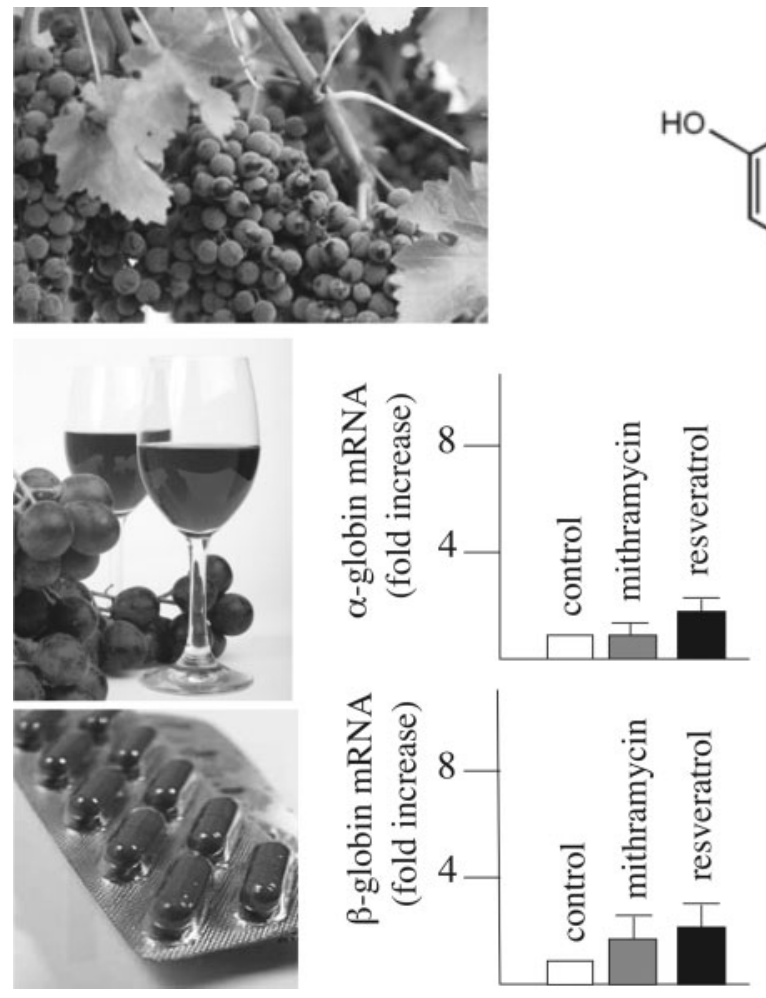

Figure 3. Resveratrol induces increase of $\gamma$-globin mRNA in human erythroid precursors. Structures of resveratrol and fold increase of $\alpha$-globin, $\beta$-globin and $\gamma$-globin mRNA in erythroid precursor cells from human healthy donors (the comparison with the effects of the HbF inducer mithramycin are shown).

In conclusion, these angular psoralen derivatives allow only monofunctional photobinding, thus reducing undesirable side effects, especially long-term ones such as genotoxicity and risk of skin cancer.

For these reasons, we focused our attention on angelicin (78). We demonstrated that angelicin is a powerful inducer of (i) erythroid differentiation of K562 cells, (ii) increase of $\mathrm{HbF}$ in erythroid progenitors from normal subjects and (iii) increase of $\gamma$-globin mRNA in erythroid precursor cells isolated from $\beta$-thalassemia patients. In the lower part of Fig. 2 is depicted a representative experiment demonstrating increase of $\gamma$-globin mRNA and $\mathrm{HbF}$ production in erythroid precursor cells treated with angelicin. Interestingly, the efficiency of the induction obtained is higher than that displayed by $\mathrm{HU}$, the most used $\mathrm{HbF}$ inducer in clinical trials of patients affected by $\beta$-thalassemia and SCA (78).

\section{Resveratrol: A HbF Inducer Mimicking the Biological Activity of Hydroxyurea}

Resveratrol (3,5,4'-trihydroxystilbene, 'E' form) (101-111) (Fig. 3 for chemical structure) is a natural phytoalexin present in large quantity in red wine, preferentially in the skin of grapes (104). The content of resveratrol is $50-100 \mu \mathrm{g} \mathrm{mg}^{-1}$ of fresh skin and $1.3-3 \mathrm{mg}^{-1}$ of red wine $(104,108)$. In addition, resveratrol is a constituent of
'Darakchasava' (1.3-6 $\left.\mathrm{mg}^{-1}\right)$, an ayurvedic medicine from India (102).

This polyphenol has been demonstrated to inhibit ribonucleotide reductase with an efficiency higher than HU (105). Rodrigue et al. (101) found that resveratrol possesses similar properties to $\mathrm{HU}$ toward erythroid differentiation. They firmly demonstrated that resveratrol induces differentiation of K562 cells and augmentation of $\mathrm{HbF}$ in erythroid precursor cells isolated from eight sickle cell patients. Comparative analyses demonstrated that resveratrol, as $\mathrm{HU}$, inhibits intracellular adhesion molecule-1 (ICAM-1) and VCAM-1 expression by endothelial cells. In addition, resveratrol possesses other properties similar to $\mathrm{HU}$, including induction of nitric oxide synthase in cultured pulmonary endothelial cells and inhibition of human platelet aggregation in vitro. Interestingly, resveratrol exhibited minimal toxicity on normal hematopoietic cells, as suggested by Clément et al. (111).

In our laboratory, when erythroid precursor cells from normal subjects were treated with increasing concentrations of resveratrol and analysis of accumulation of globin mRNA sequences was performed by quantitative RT-PCR, a clear increase in accumulation of $\gamma$-globin mRNA content was found (lower part of Fig. 3). Increase in accumulation of $\alpha$-globin and $\beta$-globin mRNA was much lower. Taken together these data strongly indicate resveratrol as a strong inducer of $\mathrm{HbF}$ and a selective stimulator of the expression in $\gamma$-globin genes. 

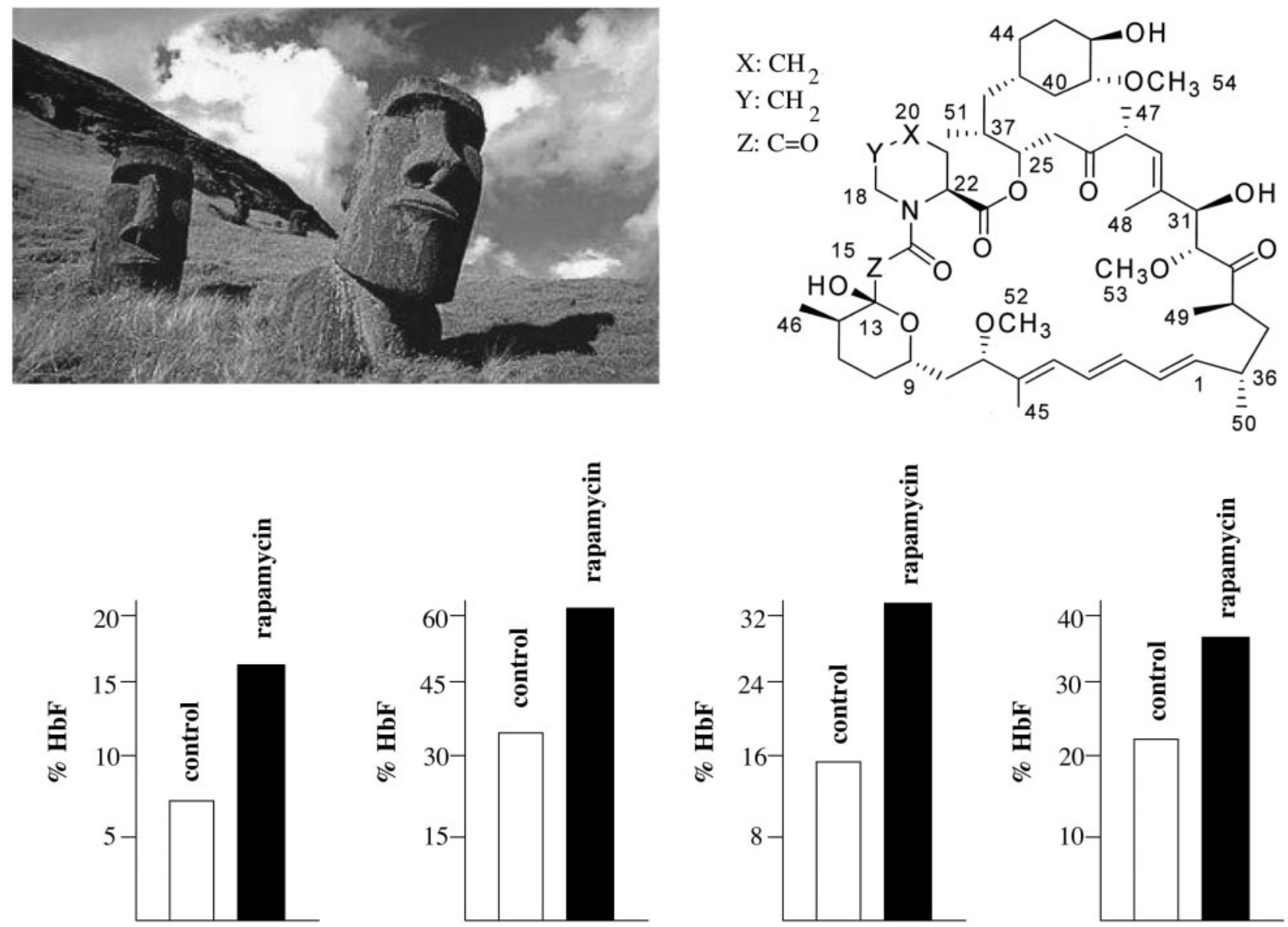

Figure 4. Induction of HbF by rapamycin. Molecular structure of rapamycin, isolated from a strain of S. hygroscopicus found in the soil of Easter Island. The effects of rapamycin on HbF production are shown in lower side of the panel. HbF was analyzed by HPLC in erythroid precursor cells from four $\beta$-thalassemia patients (open boxes, control untreated cells; black boxes, rapamycin induced cells). The data are from Fibach et al. (116).

\section{Rapamycin: Novel Applications as Inducer of Fetal Hemoglobin}

Rapamycin (Fig. 4), a lipophilic macrolide isolated from a strain of Streptomyces hygroscopicus found in a soil from Easter Island (known by the inhabitants as Rapa Nui) $(112,113)$, is of great interest for possible treatment of $\beta$-thalassemia. We recently demonstrated that rapamycin induces erythroid differentiation of K562 cells and increases $\mathrm{HbF}$ production in primary human erythroid precursor cells (114). Interestingly, Rapamycin (as Sirolimus or Rapamune) was approved by the U.S. Food and Drug Administration for prevention of acute rejection in renal transplant recipients. Moreover, the dosages we found effective in vitro are very similar to those described to be present in the blood of kidney transplanted patients treated with rapamycin (115). In a more recent paper, we determined whether rapamycin treatment stimulates production of $\mathrm{HbF}$ in cultures of erythroid precursors isolated from $\beta$-thalassemia patients differing widely with respect to their potential to produce $\mathrm{HbF}$, ranging from $4.6 \%$ to $93.7 \%$ of total $\mathrm{Hb}$. The results indicated that: (i) rapamycin increases
$\mathrm{HbF}$, even if the starting levels of $\mathrm{HbF}$ were sharply different (lower part of Fig. 4), (ii) rapamycin increases the overall $\mathrm{Hb}$ content/cell, (iii) the inducing effects of rapamycin are selective for $\gamma$-globin mRNA accumulation, being only minor for $\beta$-globin and none for $\alpha$-globin mRNAs and (iv) there is a strong correlation between the increase in the $\mathrm{HbF}$ and the increase in $\gamma$-globin mRNA content (116).

The interest in rapamycin-inducing $\mathrm{HbF}$ increase is related to the fact that this effect is not associated with cytotoxicity and cell growth inhibition, in contrast to effects observed with several other inducers (114). As far as mechanism of action of this and related compounds is concerned, it was found that rapamycin-mediated erythroid induction is associated with a decrease of phosphorylation of $\alpha$-p-S6 ribosomal protein and with a hyper phosphorylation of 4E-BP-1 (116). Furthermore, we found that inactivation of both 4E-BP-1 and p70-S6K are required steps sufficient to induce erythroid differentiation. In fact, we induced differentiation when these molecular events were simultaneously produced by a mixture of drugs involved in downstream alterations of the FRAP-mTOR signal transduction pathway (116). 
As a final comment, we underline that these results are of clinical importance, since this agent is already in use as an antirejection agent following kidney transplantation (115). In these patients, rapamycin reaches steady-state blood concentrations similar to those we found to induce $\mathrm{HbF}$, suggesting that this and structurally related molecules, warrant careful evaluation as potential drugs for stimulation of $\gamma$-globin gene expression and increase of $\mathrm{HbF}$ in patients with $\beta$-thalassemia and SCA (114,116).

Among rapamycin analogues, everolimus has been recently demonstrated to be very active in inducing erythroid differentiation, increase of $\gamma$-globin gene expression and $\mathrm{HbF}$ production. Everolimus is of interest since it exhibits improved pharmacokinetics characteristics, increased oral bioavailability, and rapid achievement of steady-state levels (117).

\section{Final Remarks and Future Perspectives}

Induction of $\mathrm{HbF}$ in patients affected by $\beta$-thalassemia and sickle cell anemia (SCA) has been suggested as a very promising approach for the conversion of those patients to an independency from blood transfusion $(14,24-29,67)$.

Thalassemia and SCA are the major health problems in developing countries, when affected patients and healthy carriers are numerous, mainly due to the absence of genetic counseling and prenatal diagnosis $(2,3,55)$.

It should be pointed out that pharmacological therapy of $\beta$-thalassemia is expected to be crucial for several developing countries, unable to efficiently sustain the high-cost clinical management of $\beta$-thalassemia patients requiring regular transfusion regimen, chelation therapy and advanced hospital facilities. It is well known that, in addition to 'direct costs', blood transfusions required accurate monitoring of blood safety, by using costly technologies, some of which are based on multiple PCR covering all the possible hematological infectious diseases (55).

Alternative therapeutic approaches, gene therapy $(118,119)$ and bone-marrow transplantation $(120,121)$ are interesting strategies, but are expected to be useful only for a minority of patients, selected on the basis of biological/genetic parameters and the economic possibility to sustain these strategies.

On the other hand, large investments by pharmaceutical companies finalized to the design, production and testing of novel drugs for the treatment of $\beta$-thalassemia is discouraged by the fact that this pathology is a rare disease in developed countries, due to the recurrent campaigns for prevention, genetic counseling and prenatal diagnosis (55). Therefore, the search for molecules exhibiting the property of inducing $\gamma$-globin gene expression is of great interest.
This review was finalized to sustain the concept that among drugs identified from material from the natural world (for instance extracts from medicinal plants), some of them might exhibit the capability to augment $\mathrm{HbF}$.

We firmly believe that this field will be exciting from the scientific point of view, but also represent a hope for several patients, whose survival will depend on the possible use of drugs rendering unnecessary blood transfusion and chelation therapy.

\section{Acknowledgments}

R.G. received grants from AIRC, Fondazione Cassa di Risparmio di Padova e Rovigo, Cofin-2002, from Ricerca Finalizzata 2001 (Ministero Superiore di Sanità), from UE ITHANET Project (eInfrastructure for Thalassemia Network Research) and from Telethon (contract GGP07257). This research is also supported by Regione Emilia-Romagna (Spinner Project), by Associazione Veneta per la Lotta alla Talassemia (AVLT) and by STAMINA Project of Ferrara University.

\section{References}

1. Steinberg MH, Forget BG, Higgs DR, Nagel RL. Disorders of Hemoglobin: Genetics, Pathophysiology and Clinical Management. Cambridge, UK: Cambridge University Press, 2001.

2. Thein SL. Genetic insights into the clinical diversity of beta thalassaemia. Br J Haematol 2004;124:264-74.

3. Old JM. Screening and genetic diagnosis of haemoglobin disorders. Blood Rev 2003;17:43-53.

4. Thein SL. Beta-thalassaemia prototype of a single gene disorder with multiple phenotypes. Int J Hematol 2002;76:96-104.

5. Fucharoen S, Winichagoon P. Thalassemia and abnormal hemoglobin. Int J Hematol 2002;76:83-9.

6. Schrier SL. Pathophysiology of thalassemia. Curr Opin Hematol 2002;9:123-6.

7. Wonke B. Clinical management of beta-thalassemia major. Semin Hematol 2001;38:350-9.

8. Hardison RC, Chui DH, Giardine B, Riemer C, Patrinos GP, Anagnou N, et al. HbVar: A relational database of human hemoglobin variants and thalassemia mutations at the globin gene server HbVar. Hum Mutat 2002;19:225-33.

9. Patrinos GP, Giardine B, Riemer C, Miller W, Chui DH, Anagnou NP, et al. Improvements in the HbVar database of human hemoglobin variants and thalassemia mutations for population and sequence variation studies. Nucleic Acids Res 2004;1:537-41.

10. Kutlar A. Sickle cell disease: a multigenic perspective of a single gene disorder. Hemoglobin 2007;31:209-24.

11. Frenette PS, Atweh GF. Sickle cell disease: old discoveries, new concepts, and future promise. J Clin Invest 2007;117:850-8.

12. Osti F, Corradini FG, Hanau S, Matteuzzi M, Gambari R. Human leukemia K562 cells: induction to erythroid differentiation by guanine, guanosine and guanine nucleotides. Haematologica 1997;82:395-401.

13. Lampronti I, Bianchi N, Zuccato C, Medici A, Bergamini P, Gambari R. Effects on erythroid differentiation of platinum(II) complexes of synthetic bile acid derivatives. Bioorg Med Chem 2006; 14:5204-10

14. Olivieri NF. Reactivation of fetal hemoglobin in patients with betathalassemia. Semin Hematol 1996;33:24-42.

15. Blau CA, Stamatoyannopoulos G. Hemoglobin switching and its clinical implications. Curr Opin Hematol 1994;1:136-42.

16. Forget BG. Molecular basis of hereditary persistence of fetal hemoglobin. Ann N Y Acad Sci 1998;850:38-44. 
17. Bhardwaj U, McCabe ER. Multiplex-PCR assay for the deletions causing hereditary persistence of fetal hemoglobin. Mol Diagn 2005;9:151-6.

18. Liu LR, Du ZW, Zhao HL, Liu XL, Huang XD, Shen J, et al. T to $\mathrm{C}$ substitution at- 175 or-173 of the gamma-globin promoter affects GATA-1 and Oct-1 binding in vitro differently but can independently reproduce the hereditary persistence of fetal hemoglobin phenotype in transgenic mice. $J$ Biol Chem 2005;280:7452-9.

19. Garner C, Dew TK, Sherwood R, Rees D, Thein SL. Heterocellular hereditary persistence of fetal haemoglobin affects the haematological parameters of beta-thalassaemia trait. $\mathrm{Br} \quad J$ Haematol 2003; 123:353-8.

20. Lal A, Vichinsky E. The role of fetal hemoglobin-enhancing agents in thalassemia. Semin Hematol 2004;41:17-22.

21. Rodgers GP, Dover GJ, Uyesaka N, Noguchi CT, Schechter AN, Nienhuis AW. Augmentation by erythropoietin of the fetalhemoglobin response to hydroxyurea in sickle cell disease. $N$ Engl $J$ Med 1993;328:73-80.

22. Rodgers GP, Rachmilewitz EA. Novel treatment options in the severe beta-globin disorders. Br J Haematol 1995;91:263-8.

23. Steinberg MH, Lu LZ, Barton FB, Terrin ML, Charache S, Dover GJ. Fetal hemoglobin in sickle cell anemia: determinants of response to hydroxyurea. Multicenter Study of Hydroxyurea. Blood 1997;89:1078-88.

24. Olivieri NF, Rees DC, Ginder GD, Thein SL, Waye JS, Chang L, et al. Elimination of transfusions through induction of fetal hemoglobin synthesis in Cooley's anemia. Ann $N$ Y Acad Sci 1998;850:100-9.

25. Swank RA, Stomatoyannopoulos G. Fetal gene reactivation. Curr Opin Genet Dev 1998;8:366-70.

26. Cao H. Pharmacological induction of fetal hemoglobin synthesis using histone deacetylase inhibitors. Hematology 2004;9:223-33.

27. Lo L, Singer ST. Thalassemia: current approach to an old disease. Pediatr Clin North Am 2002;49:1165-91.

28. Atweh GF, Loukopoulos D. Pharmacological induction of fetal hemoglobin in sickle cell disease and beta-thalassemia. Semin Hematol 2001;38:367-73.

29. Olivieri NF, Weatherall DJ. The therapeutic reactivation of fetal haemoglobin. Hum Mol Genet 1998;7:1655-8.

30. Yavarian M, Karimi M, Bakker E, Harteveld CL, Giordano PC. Response to hydroxyurea treatment in Iranian transfusion-dependent beta-thalassemia patients. Haematologica 2004;89:1172-8.

31. Bradai M, Abad MT, Pissard S, Lamraoui F, Skopinski L, de Montalembert M. Hydroxyurea can eliminate transfusion requirements in children with severe beta-thalassemia. Blood 2003;102:1529-30.

32. Alebouyeh M, Moussavi F, Haddad-Deylami H, Vossough P. Hydroxyurea in the treatment of major beta-thalassemia and importance of genetic screening. Ann Hematol 2004;83:430-3.

33. Dixit A, Chatterjee TC, Mishra P, Choudhry DR, Mahapatra M, Tyagi S, et al. Hydroxyurea in thalassemia intermedia-a promising therapy. Ann Hematol 2005;84:441-6.

34. Karimi M, Darzi H, Yavarian M. Hematologic and clinical responses of thalassemia intermedia patients to hydroxyurea during 6 years of therapy in Iran. $J$ Pediatr Hematol Oncol 2005:27:380-5.

35. Singer ST, Kuypers FA, Olivieri NF, Weatherall DJ, Mignacca R, Coates TD, et al. Fetal haemoglobin augmentation in $\mathrm{E} /$ beta $(0)$ thalassaemia: clinical and haematological outcome. Br J Haematol 2005; 131:378-88.

36. Watanapokasin R, Sanmund D, Winichagoon P, Muta K, Fucharoen S. Hydroxyurea responses and fetal hemoglobin induction in beta-thalassemia/HbE patients' peripheral blood erythroid cell culture. Ann Hematol 2006;85:164-9.

37. Watanapokasin Y, Chuncharunee S, Sanmund D, Kongnium W, Winichagoon P, Rodgers GP, et al. In vivo and in vitro studies of fetal hemoglobin induction by hydroxyurea in beta-thalassemia/ hemoglobin E patients. Exp Hematol 2005;33:1486-92.

38. Marianna P, Kollia P, Akel S, Papassotiriou Y, Stamoulakatou A, Loukopoulos D. Valproic acid, trichostatin and their combination with hemin preferentially enhance gamma-globin gene expression in human erythroid liquid cultures. Haematologica 2001;86:700-5.
39. Singer ST, Kuypers FA, Olivieri NF, Weatherall DJ, Mignacca R, Coates TD, et al. Single and combination drug therapy for fetal hemoglobin augmentation in hemoglobin E-\{beta\}0Thalassemia: considerations for treatment. Ann N Y Acad Sci 2005; 1054:250-6.

40. Fathallah H, Atweh GF. DNA hypomethylation therapy for hemoglobin disorders: molecular mechanisms and clinical applications. Blood Rev 2006;20:227-34.

41. DeSimone J. The evolving role of DNA demethylating agents in the treatment of sickle cell disease and thalassemia. Semin Hematol 2004;41:1-3.

42. Perrine SP, Ginder GD, Faller DV, Dover GH, Ikuta T, Witkowska HE, et al. A short-term trial of butyrate to stimulate fetal-globin-gene expression in the beta-globin disorders. $N$ Engl $J$ Med 1993;328:81-6.

43. Skarpidi E, Vassilopoulos G, Li Q, Stamatoyannopoulos G. Novel in vitro assay for the detection of pharmacologic inducers of fetal hemoglobin. Blood 2000;96:321-6.

44. Vadolas J, Wardan H, Orford M, Williamson R, Ioannou PA. Cellular genomic reporter assays for screening and evaluation of inducers of fetal hemoglobin. Hum Mol Genet 2004;13:223-33.

45. Vadolas J, Wardan H, Orford M, Voullaire L, Zaibak F, Williamson R, et al. Development of sensitive fluorescent assays for embryonic and fetal hemoglobin inducers using the human betaglobin locus in erythropoietic cells. Blood 2002;100:4209-16.

46. Lozzio CB, Lozzio BB. Human chronic myelogenous leukemia cell-line with positive Philadelphia chromosome. Blood 1975;45:321-34.

47. Rutherford T, Clegg JB, Higgs DR, Jones RW, Thompson J, Weatherall DJ. Embryonic erythroid differentiation in the human leukemic cell line K562. Proc Natl Acad Sci USA 1981;78:348-52.

48. Rutherford TR, Clegg JB, Weatherall DJ. K562 human leukaemic cells synthesise embryonic haemoglobin in response to haemin. Nature 1979;280:164-5.

49. Bianchi N, Chiarabelli C, Borgatti M, Mischiati C, Fibach E, Gambari R. Accumulation of gamma-globin mRNA and induction of erythroid differentiation after treatment of human leukaemic K562 cells with tallimustine. Br J Haematol 2001;113:951-61.

50. Bianchi N, Ongaro F, Chiarabelli C, Gualandi L, Mischiati C, Bergamini $\mathrm{P}$, et al. Induction of erythroid differentiation of human K562 cells by cisplatin analogs. Biochem Pharmacol 2000;60:31-40.

51. Bianchi N, Osti F, Rutigliano C, Corradini FG, Borsetti E, Tomassetti $\mathrm{M}$, et al. The DNA-binding drugs mithramycin and chromomycin are powerful inducers of erythroid differentiation of human K562 cells. Br J Haematol 1999;104:258-65.

52. Fibach E, Manor D, Oppenheim A, Rachmilewitz EA. Proliferation and maturation of human erythroid progenitors in liquid culture. Blood 1989;73:100-3.

53. Fibach E, Kollia P, Schechter AN, Noguchi CT, Rodgers GP. Hemin-induced acceleration of hemoglobin production in immature cultured erythroid cells: preferential enhancement of fetal hemoglobin. Blood 1995;85:2967-74.

54. Fibach E, Rachmilewitz EA. Stimulation of erythroid progenitors by high concentrations of erythropoietin results in normoblasts arrested in G2 phase of the cell cycle. Exp Hematol 1993;21:184-8.

55. Gambari R, Fibach E. Medicinal chemistry of fetal hemoglobin inducers for treatment of beta-thalassemia. Curr Med Chem 2007;14:199-212.

56. Heinrich M, Gibbons S. Ethnopharmacology in drug discovery: an analysis of its role and potential contribution. $J$ Pharm Pharmacol 2001;53:425-32.

57. Saad B, Azaizeh H, Said O. Tradition and perspectives of arab herbal medicine: a review. Evid Based Complement Alternat Med 2005;2:475-9.

58. Khan MT, Lampronti I, Martello D, Bianchi N, Jabbar S, Choudhuri MS, et al. Identification of pyrogallol as an antiproliferative compound present in extracts from the medicinal plant Emblica officinalis: effects on in vitro cell growth of human tumor cell lines. Int $J$ Oncol 2002;21:187-92.

59. Luo JZ, Luo L. American ginseng stimulates insulin production and prevents apoptosis through regulation of uncoupling Protein-2 in cultured beta cells. Evid Based Complement Alternat Med 2006;3:365-72. 
60. Jagetia GC, Rao SK. Evaluation of cytotoxic effects of dichloromethane extract of guduchi (Tinospora cordifolia Miers ex Hook F \& THOMS) on cultured HeLa cells. Evid Based Complement Alternat Med 2006;3:267-72.

61. Lambertini E, Piva R, Khan MT, Lampronti I, Bianchi N, Borgatti M, et al. Effects of extracts from Bangladeshi medicinal plants on in vitro proliferation of human breast cancer cell lines and expression of estrogen receptor alpha gene. Int $J$ Oncol 2004;24:419-23.

62. Xie F, Wu CF, Lai WP, Yang XJ, Cheung PY, Yao XS, et al. The osteoprotective effect of Herba epimedii (HEP) extract in vivo and in vitro. Evid Based Complement Alternat Med 2005;2:353-61.

63. Adams LS, Seeram NP, Hardy ML, Carpenter C, Heber D. Analysis of the interactions of botanical extract combinations against the viability of prostate cancer cell lines. Evid Based Complement Alternat Med 2006;3:117-24.

64. Lampronti I, Khan MTH, Bianchi N, Ather A, Borgatti M, Vizziello L, et al. Bangladeshi medicinal plant extracts inhibiting molecular interactions between nuclear factors and target DNA sequences mimicking NF-kappaB binding sites. Med Chem 2005; 1:327-33.

65. Lampronti I, Martello D, Bianchi N, Borgatti M, Lambertini E, Piva R, et al. In vitro antiproliferative effects on human tumor cell lines of extracts from the Bangladeshi medicinal plant Aegle marmelos Correa. Phytomedicine 2003;10:300-8.

66. Alder R, Lookinland S, Berry JA, Williams M. A systematic review of the effectiveness of garlic as an anti-hyperlipidemic agent. $J \mathrm{Am}$ Acad Nurse Pract 2003;15:120-9.

67. Wang HX, Ng TB. Natural products with hypoglycemic, hypotensive, hypocholesterolemic, antiatherosclerotic and antithrombotic activities. Life Sci 1999;65:2663-77.

68. Luper S. A review of plants used in the treatment of liver disease: part 1. Altern Med Rev 1998;3:410-21.

69. Nakhai LA, Mohammadirad A, Yasa N, Minaie B, Nikfar S, Ghazanfari G, et al. Benefits of Zataria multiflora Boiss in experimental model of mouse inflammatory bowel disease. Evid Based Complement Alternat Med 2007;4:43-50.

70. Salem ML. Immunomodulatory and therapeutic properties of the Nigella sativa L. seed. Int Immunopharmacol 2005;5:1749-70 Epub 2005 Jul 1. Review.

71. Martin KW, Ernst E. Antiviral agents from plants and herbs: a systematic review. Antivir Ther 2003;8:77-90.

72. Khan MT, Ather A, Thompson KD, Gambari R. Extracts and molecules from medicinal plants against herpes simplex viruses. Antiviral Res 2005;67:107-19.

73. Leite SP, Vieira JR, de Medeiros PL, Leite RM, de Menezes Lima VL, Xavier HS, et al. Antimicrobial Activity of Indigofera suffruticosa. Evid Based Complement Alternat Med 2006;3:261-5.

74. Iyamu EW, Turner EA, Asakura T. In vitro effects of NIPRISAN (Nix-0699): a naturally occurring, potent antisickling agent. $\mathrm{Br} J$ Haematol 2002;118:337-43.

75. Wambebe C, Khamofu H, Momoh JA, Ekpeyong M, Audu BS, Njoku OS, et al. Double-blind, placebo-controlled, randomised cross-over clinical trial of NIPRISAN in patients with sickle cell disorder. Phytomedicine 2001:8:252-61.

76. Chiarabelli C, Bianchi N, Borgatti M, Prus E, Fibach E, Gambari R. Induction of gamma-globin gene expression by tallimustine analogs in human erythroid cells. Haematologica 2003;88:826-7.

77. Fibach E, Bianchi N, Borgatti M, Prus E, Gambari R. Mithramycin induces fetal hemoglobin production in normal and thalassemic human erythroid precursor cells. Blood 2003;102:1276-81.

78. Lampronti I, Bianchi N, Borgatti M, Fibach E, Prus E, Gambari R. Accumulation of gamma-globin mRNA in human erythroid cells treated with angelicin. Eur J Haematol 2003;71:189-95.

79. Dall'Acqua F, Viola G, Vedaldi D. Cellular and molecular target of psoralen. In: Hoorspool WM, Lenci F (eds). CRC Handbook of Organic Photochemistry and Photobiology. Boca Raton, USA: CRC Press, 2004, 1-17.

80. Chilin A, Marzano C, Guiotto A, Manzini P, Baccichetti F, Carlassare F, et al. Synthesis and biological activity of (hydroxymethyl)- and (diethylaminomethyl)-benzopsoralens. J Med Chem 1999;42:2936-45.
81. Bordin F, Marzano C, Baccichetti F, Carlassare F, Vedaldi D, Falcomer $\mathrm{S}$, et al. Photobiological properties of 1'-thieno4,6,4'-trimethylangelicin. Photochem Photobiol 1998:68:157-63.

82. Conconi MT, Montesi F, Parnigotto PP. Antiproliferative activity and phototoxicity of some methyl derivatives of 5-methoxypsoralen and 5-methoxyangelicin. Pharmacol Toxicol 1998;82:193-8.

83. Marzano C, Caffieri S, Fossa P, Bordin F. Activity of 3carbethoxyangelicin photolysis products. J Photochem Photobiol B 1997;38:189-95.

84. Bordin F, Dall'Acqua F, Guiotto A. Angelicins, angular analogs of psoralens: chemistry, photochemical, photobiological and phototherapeutic properties. Pharmacol Ther 1991;52:331-63.

85. Guiotto A, Rodighiero P, Manzini P, Pastorini G, Bordin F, Baccichetti $F$, et al. 6-Methylangelicins: a new series of potential photochemotherapeutic agents for the treatment of psoriasis. $J$ Med Chem 1984;27:959-67.

86. Komura J, Ikehata $\mathrm{H}$, Hosoi $\mathrm{Y}$, Riggs $\mathrm{AD}$, Ono $\mathrm{T}$. Mapping psoralen cross-links at the nucleotide level in mammalian cells: suppression of cross-linking at transcription factor- or nucleosome-binding sites. Biochemistry 2001;40:4096-105.

87. Mosti L, Lo Presti E, Menozzi G, Marzano C, Baccichetti F, Falcone G, et al. Synthesis of angelicin heteroanalogues: preliminary photobiological and pharmacological studies. Farmaco 1998;53:602-10.

88. Curini M, Cravotto G, Epifano F, Giannone G. Chemistry and biological activity of natural and synthetic prenyloxycoumarins. Curr Med Chem 2006;13:199-222.

89. Santana L, Uriarte E, Roleira F, Milhazes N, Borges F. Furocoumarins in medicinal chemistry. Synthesis, natural occurrence and biological activity. Curr Med Chem 2004;11:3239-61.

90. Okamoto T, Kobayashi T, Yoshida S. Chemical aspects of coumarin compounds for the prevention of hepatocellular carcinomas. Curr Med Chem Anticancer Agents 2005;5:47-51.

91. Scheinfeld N, Deleo V. A review of studies that have utilized different combinations of psoralen and ultraviolet B phototherapy and ultraviolet A phototherapy. Dermatol Online $J$ 2003;9:7.

92. Khurshid K, Haroon TS, Hussain I, Pal SS, Jahangir M, Zaman T. Psoralen-ultraviolet A therapy vs. psoralen-ultraviolet B therapy in the treatment of plaque-type psoriasis: our experience with Fitzpatrick skin type IV. Int $J$ Dermatol 2000;39:865-7.

93. de Berker DA, Sakuntabhai A, Diffey BL, Matthews JN, Farr PM. Comparison of psoralen-UVB and psoralen-UVA photochemotherapy in the treatment of psoriasis. $J$ Am Acad Dermatol 1997;36:577-81.

94. Morison WL. Combination of methoxsalen and ultraviolet B (UVB) versus UVB radiation alone in treatment of psoriasis: a bilateral comparison study. Photodermatol Photoimmunol Photomed 1995;11:6-8.

95. Honigsmann H. Phototherapy for psoriasis. Clin Exp Dermatol 2001;26:343-50.

96. Abel EA. Phototherapy: UVB and PUVA. Cutis 1999;64:339-42.

97. McNeely W, Goa KL. 5-Methoxypsoralen. A review of its effects in psoriasis and vitiligo. Drugs 1998;56:667-90.

98. McGinnis KS, Shapiro M, Vittorio CC, Rook AH, JunkinsHopkins JM. Psoralen plus long-wave UV-A (PUVA) and bexarotene therapy: an effective and synergistic combined adjunct to therapy for patients with advanced cutaneous T-cell lymphoma. Arch Dermatol 2003;139:771-5.

99. Zarebska Z, Waszkowska E, Caffieri S, Dall'Acqua F. PUVA (psoralen + UVA) photochemotherapy: processes triggered in the cells. Farmaco 2000;55:515-20.

100. Bisagni E. Synthesis of psoralens and analogues. $J$ Photochem Photobiol B 1992;14:23-46.

101. Rodrigue CM, Arous N, Bachir D, Smith-Ravin J, Romeo PH, Galacteros F, et al. Resveratrol, a natural dietary phytoalexin, possesses similar properties to hydroxyurea towards erythroid differentiation. Br J Haematol 2001;113:500-7.

102. Paul B, Masih I, Deopujari J, Charpentier C. Occurrence of resveratrol and pterostilbene in age-old darakchasava, an ayurvedic medicine from India. J Ethnopharmacol 1999;68:71-6.

103. Hain R, Bieseler B, Kindl H, Schroder G, Stocker R. Expression of a stilbene synthase gene in Nicotiana tabacum results in synthesis of the phytoalexin resveratrol. Plant Mol Biol 1990;15:325-35. 
104. Jeandet P, Bessis R, Gautheron B. The production of resveratrol (3,5,4-trihydroxystilbene) by grape berries in different developmental stages. Am J Enol and Vitic 1991;42:41-6.

105. Fontecave M, Lepoivre M, Elleingand E, Gerez C, Guittet O. Resveratrol, a remarkable inhibitor of ribonucleotide reductase. FEBS Letters 1998;421:277-9.

106. Frankel EN, Waterhouse AL, Kinsella JE. Inhibition of human LDL oxidation by resveratrol. Lancet 1993;341:1103-4.

107. Ferrero ME, Bertelli AE, Fulgenti A, Pellegatta F, Corsi MM, Bonfrate $\mathrm{M}$, et al. Activity in vitro of resveratrol on granulocyte and monocyte adhesion to endothelium. Am J Clin Nutrition 1998;68:1208-14.

108. Carbo N, Costelli P, Baccino FM, Lopez-Soriano FJ, Argiles JM. Resveratrol, a natural product present in wine, decreases tumour growth in a rat tumour model. Biochem Biophys Res Commun 1999;254:739-43.

109. Jang M, Cai L, Udeani GO, Slowing KV, Thomas CF, Beecher CW, et al. Cancer chemopreventive activity of resveratrol, a natural product derived from grapes. Science 1997;275:218-20.

110. Mgbonyebi OP, Russo J, Russo IH. Antiproliferative effect of synthetic resveratrol on human breast epithelial cells. Int J Oncol $1998 ; 12: 865-9$

111. Clèment MV, Hirpara JL, Chawdhury SH, Pervaiz S. Chemopreventive agent resveratrol, a natural product derived from grapes, triggers CD95 signaling-dependent apoptosis in human tumor cells. Blood 1998;92:996-1002.

112. Sehgal SN. Sirolimus: its discovery, biological properties, and mechanism of action. Transplant Proc 2003;35:S7-14.

113. Gummert JF, Ikonen T, Morris RE. Newer immunosuppressive drugs: a review. J Am Soc Nephrol 1999;10:1366-80.
114. Mischiati C, Sereni A, Lampronti I, Bianchi N, Borgatti M, Prus E, et al. Rapamycin-mediated induction of gamma-globin mRNA accumulation in human erythroid cells. $\mathrm{Br} \mathrm{J}$ Haematol 2004;126:612-21.

115. Saunders RN, Metcalfe MS, Nicholson ML. Rapamycin in transplantation: a review of the evidence. Kidney Internat 2001;59:3-16.

116. Fibach E, Bianchi N, Borgatti M, Zuccato C, Finotti A, Lampronti I, et al. Effects of rapamycin on accumulation of $\alpha$-, $\beta$ - and $\gamma$-globin mRNAs in erythroid precursor cells from $\beta$-thalassaemia patients. Eur J Haematol 2006;77:437-41.

117. Zuccato C, Bianchi N, Borgatti M, Lampronti I, Massei F, Favre C, et al. Everolimus is a potent inducer of erythroid differentiation and gamma-globin gene expression in human erythroid cells. Acta Haematol 2007;117:168-76.

118. Sadelain M, Boulad F, Galanello R, Giardina P, Locatelli F, Maggio A, et al. Therapeutic options for patients with severe $\beta$-thalassemia: the need for globin gene therapy. Hum Gene Ther 2007;18:1-9.

119. Quek L, Thein SL. Molecular therapies in beta-thalassaemia. Br J Haematol 2007;136:353-65.

120. Gaziev J, Sodani P, Polchi P, Andreani M, Lucarelli G. Bone marrow transplantation in adults with thalassemia: treatment and long-term follow-up. Ann N Y Acad Sci 2005;1054:196-205.

121. Caocci G, Pisu S, Argiolu F, Giardini C, Locatelli F, Vacca A, et al. Decision-making in adult thalassemia patients undergoing unrelated bone marrow transplantation: quality of life, communication and ethical issues. Bone Marrow Transplant 2006;37:165-9.

Received June 14, 2007; accepted August 23, 2007 


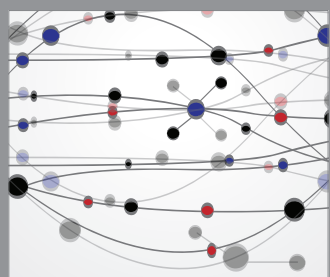

The Scientific World Journal
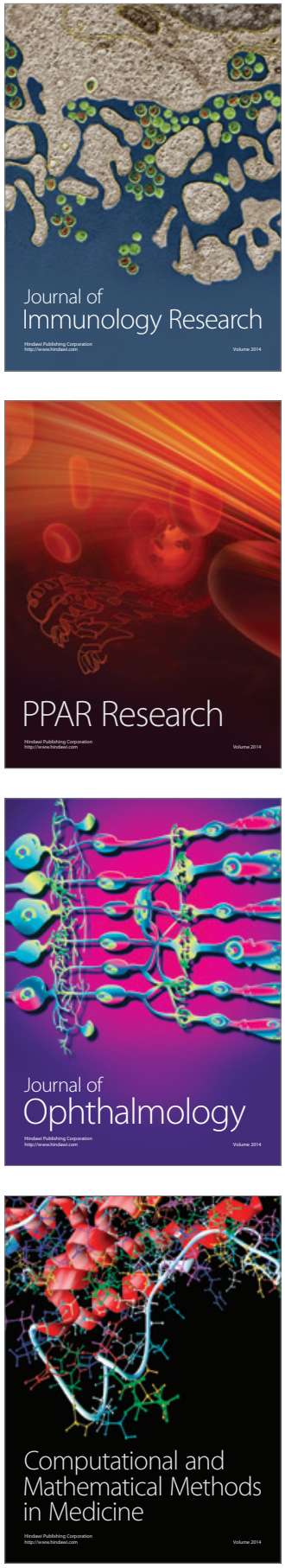

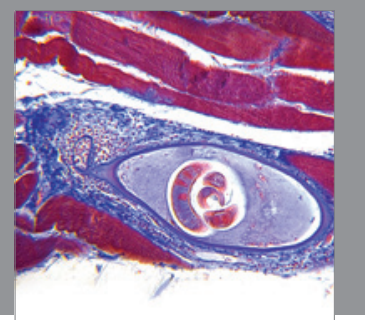

Gastroenterology

Research and Practice
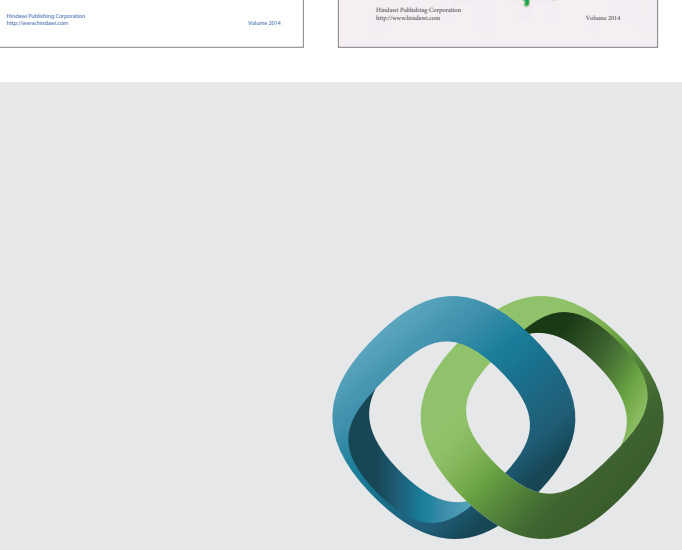

\section{Hindawi}

Submit your manuscripts at

http://www.hindawi.com
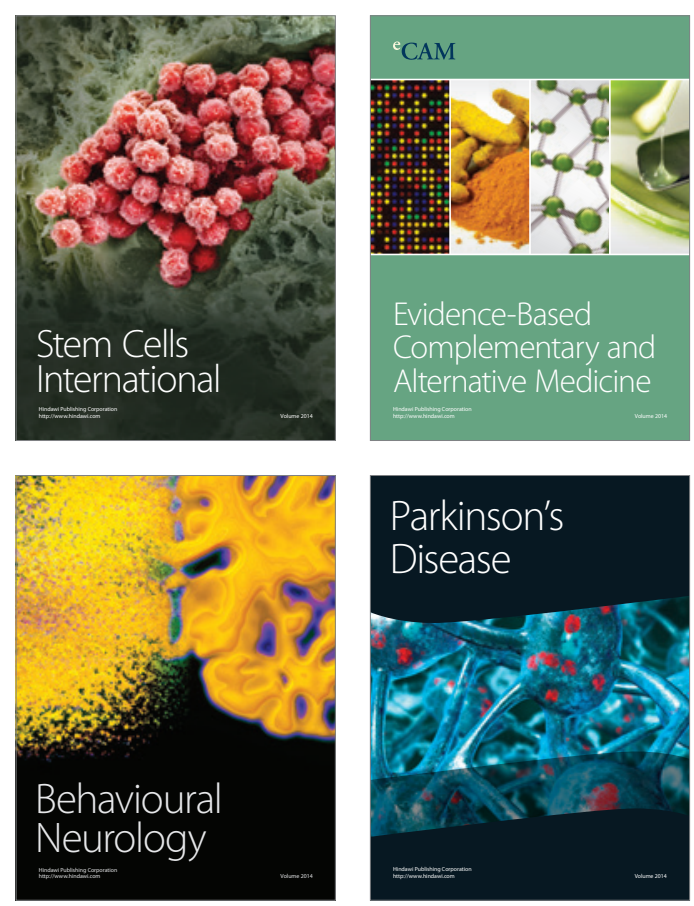

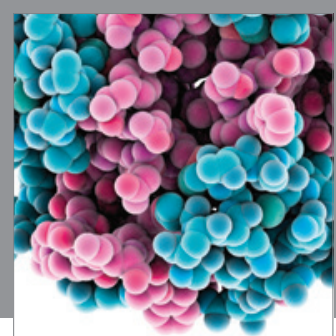

Journal of
Diabetes Research

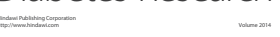

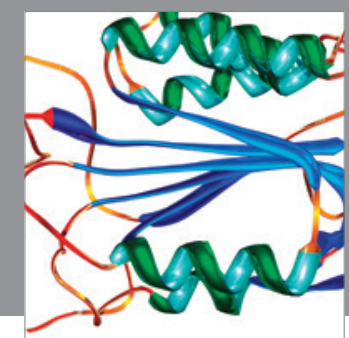

Disease Markers
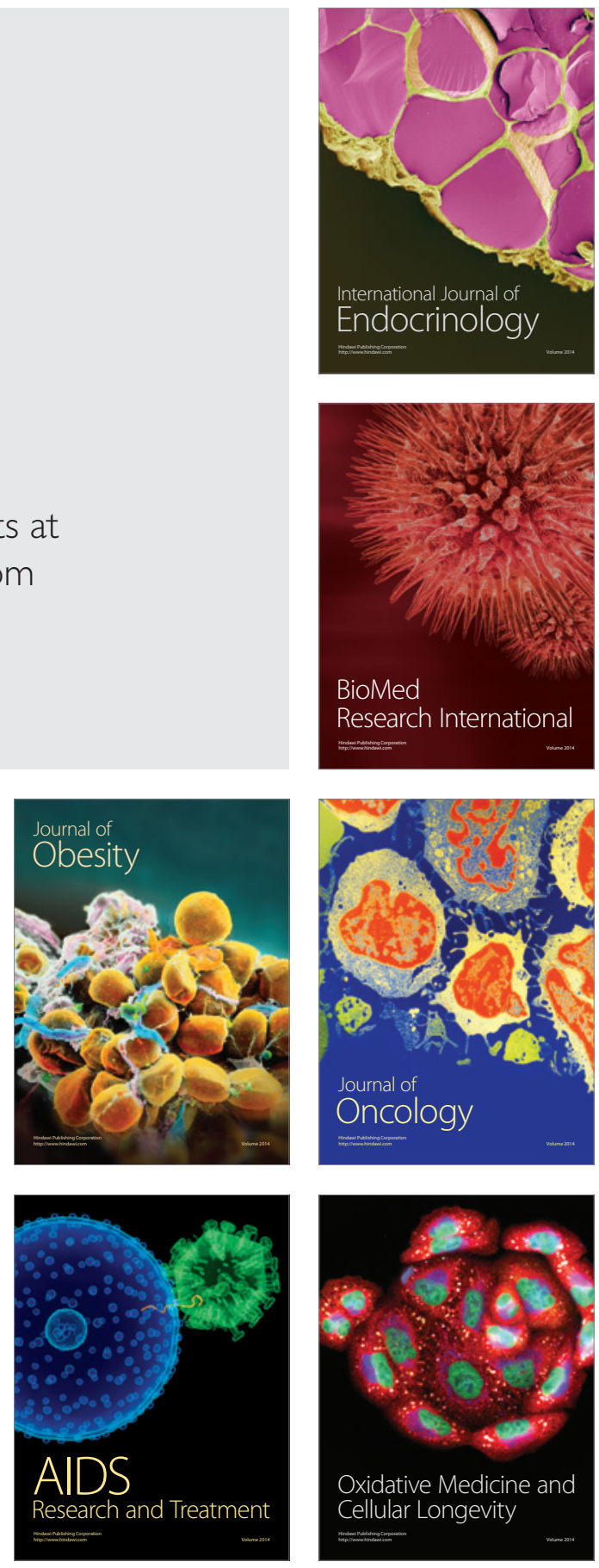